\title{
MEKANISME BERTAHAN PEDAGANG ANGKRINGAN DI ERA DISRUPSI (STUDI MODAL SOSIAL PADA PEDAGANG ANGKRINGAN DI KAWASAN JL. KI HADJAR DEWANTARA, SURAKARTA)
}

\section{Oleh:}

\section{Okta Hadi Nurcahyono}

\begin{abstract}
Abstrak
Artikel ini merupakan hasil dari penelitian lapangan yang bertujuan untuk mencari bagaimana mekanisme bertahan yang dilakukan oleh para pedagang angkringan di era disrupsi. Perkembangan zaman yang bersifat disruptif mengakibatkan struktur kehidupan masyarakat banyak mengalami perubahan, termasuk dalam hal ini adalah pedagang angkringan atau Hik. Metode yang digunakan dalam penelitian lapangan ini adalah penelitian kualtitatif dengan jenis deskriptif kualitatif. Lokasi penelitian yaitu disepanjang Jalan $\mathrm{Ki}$ Hadjar Dewantara, Kota Surakarta yang terdapat sepuluh warung angkringan atau HIK tiap malam hari. Proses pencarian data pada penelitian ini dilakukan dengan teknik observasi non partisipatif dan wawancara mendalam (in-depth interview). Hasil penelitian menunjukan bahwa para pedagang angkringan di kawasan Jalan Ki Hadjar Dewantara mendayagunakan modal social yang dimiliki untuk mendapatkan keuntungan ekonomi atau dalam rangka mempertahankan usahanya di era disrupsi saat ini. Pertama, membangun trust (kepercayaan) pelanggan dengan memberikan pelayanan maksimal, menjaga cita rasa makanan, dan memberikan tempat yang nyaman untu ngobrol. Kedua, memeperketat aturan atau norma pada para pegawainya dengan jobdesk yang sudah ada. Ketiga, membangun jaringan dengan supplier makanan dan jaringan via online sistem yaitu dengan memasukan kedalam aplikasi seperti gofood atau grabfood sehingga dapat membangun jaringan baru dengan para pengemudi ojek online.
\end{abstract}

Kata kunci: pedagang angkringan, modal social, dan era disrupsi

\section{Pendahuluan}

Negara Indonesia adalah negara yang kaya akan kuliner tradisional. Setiap daerah memiliki kekhasan kuliner tradional. Selain menjadi konsumsi harian oleh masyarakat, kuliner menjadi identitas dari daerah bahkan menjadi daya tarik pariwisata. Banyak diantara kuliner tradisional yang menjadi populer menjadi identitas suatu daerah seperti: Sate dari Madura, Soto Lamongan, Rumah Makan Padang, Warung Tegal (Warteg), Warung
Bubur Kacang Ijo (Burjo). Kesemua kuliner tersebut pasti kita bisa jumpai di hampir seluruh kota di Indonesia, karena kuliner-kuliner tersebut digemari oleh para kaum urban. Satu kuliner yang menjadi lagi yang menjadi kegemaran para kaum urban pada beberapa kota di Indonesia sperti "angkringan".

Angkringan merupakan salah satu kuliner yang berasal dari wilayah Klaten, Surakarta dan Yogyakarta. Meskipun dalam perjalanan sejarah kemunculan 
antara angkringan yang ada di Yogyakarta dan HIK (Hidangan Istemewa Kampung) yang ada di Surakarta tapi konsep berjualanya pada saat ini sama. Angkringan di Kota Yogyakarta mulai berkembang pada tahun 1950-an yang dibawa oleh seorang pedagang yang bernama Mbah Pairo dari Klaten (Qomaria; 2015).

Pada awalnya cara berjualan angkringan dengan cara dipikul menggunakan pikulan. Pikulan sebelah kiri berfungsi sebagai tempat pembakaran atau kompor untuk merebus air. Pikulan sebelah kanan sebagai tempat untuk menaruh barang dagangan. Angkring yang pada awalnya dipikul pada saat ini berubah menjadi gerobak dari kayu yang mengguankan tenda sebagai atapnya.

Angkringan di Kota Surakarta dikenal dengan istilah HIK atau singkatan dari Hidangan Istemewa Kampung. Di Kota Surakarta, pedagang HIK sendiri muncul pada tradisi malam selikuran atau akhir bulan. Nama HIK sendiri diambil dari para pedagang yang menjajakan barang dagangannya dengan cara berkeliling dan berteriak "Hik..iyeekkk", sehingga masyarakat menanggkapnya dengan istilah "HIK" (NN; 2002). Sesuai dengan penamaan istilah HIK merupakan singkatan dari Hidangan Istemewa Kampung sehingga makanan yang di jajakanpun seperti hidangan istimewa pada masyarakat kampung di perkotaan. Makanan yang dijual antara lain nasi kucing (nasi dengan ukuran kecil yang di dalamnya ada sambel dan irisan ikan bandeng), anaka gorangan, kue tradisional dan beragam minuman seperti teh dan kopi.

Pada era modern seperti pada saat ini, angkringan berkembang menyesuaikan zamannya. Tidak lagi dengan konsep berjualan dengan cara dipikul, atau dengan gerobak dengan tenda dipinggir jalan, pada saat ini angkringan sudah bertransformasi dijajakan dengan konsep cafe dengan bangunan permanen. Transfomasi pada angkringan menjadi daya tarik tersendiri, baik itu angkringan dengan yang berkonsep tradisional maupun yang berkonsep modern.

Baik angkringan yang berkonsep tradisional maupun modern memiliki konsumen atau penggemar tersendiri. Menurut Qomaria (2015) angkringan modern lebih berfungsi sebagai tempat makan, Sedangkan pada angkringan tradisional lebih menawarkan suasana keakraban baik antara penjual dan pembeli juga antar pembeli. Sehingga modal social yang terbangun diangkringan yang bersifat tradisional banyak terasa. Baik modal social penjual angkringan maupun pembeli itu sendiri. Konsep modal social ini sangat 
menarik diteliti lebih mendalam dalam kasus pedagang angkringan.

Tulisan atau artikel ilmiah mengenai angkringan sudah banyak ditulis dari hasil penelitian baik dalam bentuk skripsi, tesis, atau desertasi. Artikel yang ditulis Marfai (2005) memperlihatkan bagaimana modal social sangat bermanfaat terhadap keberadaan usaha angkringan dalam memulai usahanya. Usman dalam Qomaria (2015), meneliti kelompok pedagang angkringan di bantaran Kali Code, Yogyakarta yang memenuhi kebutuhan hidup dengan cara iuran serta menjalin kerjasama dengan para supplier yang berasal dari daerah yang sama. Sementara itu, Penelitian Santoso (2007) dan Qomaria (2015) memperlihatkan bahwa modal social digunakan para pedagang angkringan dalam rangka mempertahankan usahanya atau bertahan dalam menghadapi persaingan usaha.

Artikel ini berfokus pada pembahasan: Bagaimana pedangan angkringan melakukan investasi dalam relasi social di tengah era disrupsi seperti pada saat ini, dan bagaimana pedagang angkringan mendayagunakan sumberdaya yang melekat dalam relasi sosial tersebut untuk memperoleh keuntungan pada era disrupsi? Pada intinya melihat bagaimana individu pada pedagang angkringan melakukan meknisme bertahan (survival mechanism) di tengah persaingan usaha dan tantangan zaman.

\section{Metode Penelitian}

Penelitian ini merupakan penelitian lapangan (field research) yang menggunakan metode penelitian kualititatif, dengan jenis penelitian diskriptif kualitatif. Penelitian dilakukan pada pedagang angkringan di kawasan Jalan Ki Hadjar Dewantara, Kota Surakarta. Lokasi disini dipilih karena tergolong kawasan kampus yakni Universitas Sebelas Maret dan Institut Seni Indonesia Surakarta. Sehingga pada kawasan ini banyak kita jumpai pedagang kaki lima di sepanjang jalan yang kebanyakan menjual makanan termasuk diantaranya adalah pedagang dengan konsep angkringan. Pada Jalan Ki Hadjar Dewantara terdapat 10 warung angkringan atau wedangan tiap malam hari. Peneliti mengambil 5 pedagang angkringan sebagai sampel dalam penelitian ini.

Proses pencarian data pada penelitian ini dilakukan dengan teknik observasi non-partisipatif dengan mengamati perilaku para pedang angkrigan. Selanjutnya dilakukan proses wawancara mendalam (in-depth interview) untuk mendapatkan data verbal dari informan. Selain kedua data primer tersebut, penelitian ini mengambil data- 
data skunder dari data administrative dan penelitian terdahulu.

Setelah data berhasil dikumpulkan langkah selanjutnya adalah dilakukan analisis data kualitatif. Analisis data kualitatif yang meliputi tiga tahapan yakni: pengumpulan data, klasifikasi data, kemudian di lakukan verifikasi dan validasi. Validasi data dilakukan dengan menggunakan trianggulasi data, yaitu yang digunakan adalah trianggulasi sumber. Trianggulasi sumber dalam penelitian ini dilakukan dengan cara membandingkan atara satu sumber dengan sumber lainnya.

\section{Hasil dan Pembahasan}

Keberadaan angkringan atau HIK di Kota Surakarta memiliki kekhasan sejarah yang cukup unik, dibandingkan dengan sejarah angkringan di Kota lain seperti Yogyakarta. Sejarah angkringan di Kota Yogyakarta sudah banyak sumber sejarah mengatakan berawal dari keberadaan angkringan pertama yakni Mbah Pairo yang berasal dari Klaten kemudian menjajakan angkringannya di kawasan Tugu Yogyakarta. Sementara itu di Kota Surakarta atau Solo sejarah perkembangan angkringan atau orang solo menyebutnya dengan warung HIK dipengaruhi oleh kondisi sosial budaya masyarakat. Menurut Priyatmoko (2013) warga Solo atau Surakarta merupakan komunitas yang suka jagongan, nongkrong atau orang Solo menyebutnya "nglaras".

Jagongan atau nongkrong biasa dilakukan orang Solo atau Surakarta di malam hari, sembari beristirahat dan menghilangkan stres karena seharian bekerja. Bagi Priyatmoko (2013) bagi komunitas yang suka "nglaras" tidak berlaku istilah waktu malam digunakan untuk istirahat penuh untuk memulihkan tenaga selepas seharian bekerja. Selain menerapkan istilah "nglaras" Wong Solo sejak dahulu juga menikmati "kluyuran" (berpergian ke luar rumah) di malam hari hanya sekedar nongkrong di depan rumah atau dikenal istilah jagongan (mengobrol) ngalor ngidul (bicara omong kosong) bersama tetangga atau teman (Priyatmoko; 2013).

Berdasarkan catatan sejarah menurut Priyatmoko (2013), perkembangan angkringan atau HIK di Kota Solo atau Surakarta tidak dapat dipisahkan dari sejarah keberadaan listrik pertama di tahun 1902. Keberadaan listrik menambah geliat malam di Kota Solo yang relatif sepi. Geliat malam ini ditunjukan melalui pertunjukan layar tancap di alun-alun, bioskop di taman Sriwedari dan di gedung Abipraya singosaren dan Societet Harmony. Para penikmat malam yang telah selesai menonton bioskop, layar tancap atau 
wayang orang mereka tentunya lapar dan membutuhkan tempat untuk nongkrong, disinilah keberadaan angkringan mulai bermunculan di Kota Surakarta.

Keberadaan angkringan tentunya tidak lepas dari tempat-tempat keramaian. Begitu juga keberadaan warung angkringan di Kota Surakarta, kita bisa menjumpainya di beberapa tempat keramian dan jalan-jalan protokol seperti: Jalan Slamet Riyadi, Jalan Urip Sumoharjo dan Veteran dan beberapa ruas jalan lainnya. Pada artike ini peneliti mengambil sampel warung angkringan yang berada di kawasan Jalan Ki Hadjar Dewantara.

Jalan Ki Hadjar Dewantara merupakan salah satu titik keramaian yang ada di Kota Surakarta. Hal ini dikarenakan jalan tersebut melintasi beberapa kampus seperti Universitas Sebelas Maret, Institut Seni Indonesia, STIKES Aisyiyah, dan Solo Teknopark. Jalan Ki Hadjar Dewantara melintas sejauh $2 \mathrm{~km}$ di wilayah timur Kota Surakarta. Selain beberapa kampus jalan ini juga melintasi tempat hiburan penting yaitu Kebun Binatang Jurug. Sehingga kita bisa membayangkan bagaimana ramainya jalan Ki Hadjar Dewantara baik siang maupun malam. Terlebih pada malam hari ketika para mahasiswa yang tinggal atau kost di daerah itu keluar untuk makan malam atau nongkrong dan menghabiskan malam.
Berada di wilayah kampus menjadikan jalan ini selalu ramai oleh mahasiswa yang berlalu-lalang, baik siang maupun malam hari. Terlebih di wilayah depan gerbang Kampus ISI atau dikenal dengan sebutan gerbang kapal. Dengan ramainya mahasiswa menjadi daya tarik untuk para penjual makanan dan minuman menjajakan barang dagangannya. Kebanyakan para pedagang menjajakan barang dagangnya di trotoar atau pinggir jalan atau disebut sebagai pedagang kaki lima (PKL). Banyak sekali PKL di tempat ini, kebanyakan mereka menjual makanan dan minuman dengan jenis beragam. Baik makanan berat maupun ringan serta beberapa jenis minuman. Salah satunya adalah jenis pedagang angkrigan atau Hik. Berikut gambar angringan di depan gerbang kampus ISI Surakarta dimalam hari:

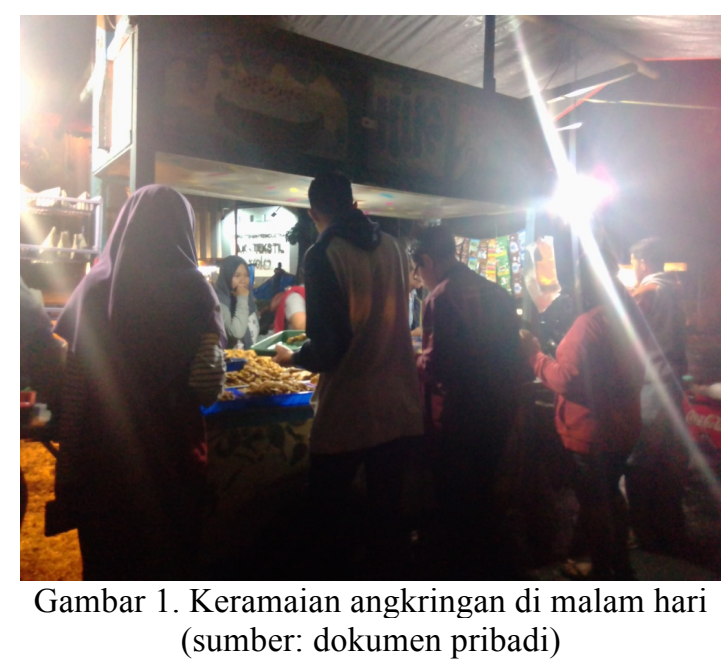




\section{Modal Sosial Pedagang Angkringan}

Angkringan adalah satu usaha nonformal yang banyak diminati masyarakat Solo dan sekitarnya. Hal ini dikarenakan untuk mendirikan usaha jenis ini relative tidak memerlukan modal yang banyak. Cukup bermodalkan gerobak dan mengelola makanan yang tidak terlalu berat, bahkan beberapa pedagang angkringan yang dijumpai pada saat penelitian hanya bermodalkan modal social. Misalnya gerobak dengan cara menyewa, sementara makanan sudah ada yang mengirim dengan system titip. Bahkan ada penjual yang memulai usahanya dengan cara meminjam dari KUR (Kredit Usaha Rakyat). Seperti Tonkiss (2000) modal social ini bernilai ekonomis kalau dapat membantu individu atau kelompok mengakses sumber-sumber keuangan, mendapatkan informasi, menemukan pekerjaan, merintis usaha, dan meminimalkan biaya transakasi.

Maka penelitian melihat bagaimana strategi yang di lakukan oleh para pedagang angkringan dalam memulai, dan mempertahankan usahanya hingga era disrupsi seperti sekarang ini. Hal ini menjadi sangat menarik untuk diteliti. Mereka mampu bertahan dan terus berkembang ditengah persaingan usaha warung makan yang semakin ketat.
Terlebih pada zaman atau era disrupsi para pedagang selaian berkompetisi dengan sesame pedagang juga harus dapat menyesuaikan tuntutan zaman, jika tidak maka akan ketinggalan dan bahkan bisa merugi.

Modal Sosial bagi Nan Lin berfokus pada akses actor individu dan bagaiamana meberdayagunakan modal social untuk mendapatkan keuntungan ekonomi atau manfaat social, termasuk dalam upaya mereka mengembangkan tindakan-tindakan yang memiliki prospek lebih baik (Usman.2018: 35). Bagi Nan Lin pengembangan konsep modal social tampak tumbuh dengan konsep modal manusia (human capital).

Seperti halnya Ibu Mulyani telah terkenal di kalangan konsumen dengan sebutan HIK Mami atau HIK Kapal (Karena berada di bawah gapura ISI Surakarta yang berbentuk kapal). Ibu Mulyani atau Mami memulai usahanya sejak 2002 dengan bermodalkan Rp.200.000,-. Dengan mendayagunakan modal social yang dimilikinya pada saat ini omzet per-hari jika kondisi ramai bisa mencapai Rp 2.000.000/hari, sedangkan jika sedang sepi hanya sekitar Rp 1.000.000/hari sampai dengan Rp 1.500.000/hari. Selain itu, Ibu Mulyani mampu memperkerjakan enam orang karyawan dengan rata-rata upah karyawan 
sebesar Rp.100.000,-. Semantara rata-rata modal yang dikeluarkan untuk produksi sebesar Rp.600.000/hari. Sehingga setiap harinya rata-rata Ibu Sri Mulyani mendapatkan laba bersih Rp.800.000/hari jika warung HIK dalam kondisi ramai pengunjung. Jika dilihat modal yang dikeluarkan 17 tahun yang lalu dengan laba yang di dapatkan perharinya bisa empat kali lipat. Hal ini tidak lepas dari strategi Ibu Sri Mulyani atau HIK Mami mendayagunakan modal social sial yang dimilikinya untuk mendapatkan keuntungan yang sebesar-besarnya.

\section{Mendayagunakan Modal Sosial pada}

\section{Era Disrupsi}

Angkringan adalah satu jenis usaha di sekotor informal yang mampu bertahan berpuluh-puluh tahun yang lalu. Bertahannya angkringan sebagai salah satu usaha alternatif di masyarakat karena memang konsepnya yang otentik dan bisa dikembangkan sesuai dengan tuntutan jaman. Misalnya sekarang ini banyak angkringan yang sudah dimodifikasi cafecefe modern. Meskipun proses tranformasi angkringan menuju modern tetapi tidak menghilangkan identitasnya sebagai kuliner tradisional(Yudhistira et al.; 2018).

Untuk mempertahankan usaha angkringannya para pedangan melakukan berbagai macam strategi, salah satunya dengan modal social. Terlebih dengan jaman yang disrupsi saat ini para pedaganga angkringan dituntut dapat mempertahankan dan sekaligus mengembangkan usahnya. Menurut Putnam (Usman; 2018) ada tiga komponen modal social yakni: trust (kepercayaan), norma dan obligasi, dan jejaring social.

Trust (kepercayaan). Membangun kepercayaan dari konsumen khususnya adalah salah satu kunci keberhasilan usaha. Begitulah yang diterapkan oleh HIK Mami atau angkringan Ibu Sri Mulyani. Strategi membangun dan menjaga kepercayaan konsumen ini diterapkan HIK Ibu Sri Mulyani selama 17 tahun sehingga dapat mempertahankan usaha angkringannya.

Strategi membangun kepercayaan dan konsumen adalah salah satu mekanisme survival yang dilakukan oleh pedagang angkringan atau HIK. Dalam hal ini, kuncinya yaitu pada citarasa makanan yang khas. Menurut konsumen, meskipun variasi makanan yang tersaji dalam HIK Mami sama dengan HIK lainnya, namun untuk rasa memang lebih juara HIK Mami. Sehingga tak aneh bila melihat konsumen yang membanjiri HIK Mami. Selain dari cita rasa yang ditawarkan, keunggulan lainnya yaitu dari nuansa HIK yang begitu asyik dan nyaman untuk sekedar ngobrol dan diskusi. Tempatnya cukup strategis 
dan luas. Konsumen yang ingin menikmati hidangan HIK dapat berada pada pelataran samping kanan dan kiri Gapura Kapal, sekitaran taman dan bahkan bisa juga di bagian atas. Ditambah dengan letaknya di pinggir jalan, menambah syahdu anakanak untuk nongkrong, meskipun hanya beralaskan dengan tikar.

Dari sisi konsumen, pembeli yang datang ke warung HIK tidak hanya semata-mata didorong oleh motif ekonomi (hanya membeli makanan dan minuman), tetapi didorong oleh motif yang lain yaitu membutuhkan tempat yang nyaman untuk bersantai, mengobrol dan berdiskusi. Kebanyakan pembeli merasa nyaman untuk singgah berlama-lama di warung HIK. Hal tersebut disebabkan, di samping minuman dan jajanan yang disajikan cukup bervariasi dan dapat memesan jajanan yang dibakar, mereka juga dapat memilih tempat duduk yang disukai untuk bersantai, baik di kursi yang telah disediakan ataupun tempat duduk lesehan di trotoar dengan beralaskan tikar. Karena suasana tradisional dan sifatnya yang masih menganut kebersamaan pengunjung inilah maka HIK Mami menjadi suatu usaha yang tetap bertahan dan banyak diminati oleh masyarakat.

Selain membangun dan menjaga kepercayaan dari konsumen para pedagang angkringan di kawasan Jalan Ki Hadjar
Dewantara, juga membangun dan menjaga kepercayaan dengan stake holder. Stake holder disini adalah pihak pemerintah yang setiap malam menarik restribusi. Selain itu antara lain: pihak distributor makanan, pegawai, juragan (bagi pedagang angkringan yang bukan milik sendiri), tukang parkir dan sebagainya.

Norma. Untuk menjaga kepercayaan pelanggan maka para pedagang angkringan menjaga kualitas pelayanan dan barang yang disajikan. Dalam menjaga kualitas tersebut diperlukan aturan yang tepat untuk para pelayan, begitu yang dilakukan oleh HIK Mami atau Angkringan Kapal. Para karyawan tersebut bekerja mulai dari pukul 08.00 WIB dengan jobdesk memasak beragam makanan yang digunakan untuk dijual hingga pukul 15.00 WIB. Setelah itu, dengan karyawan yang sama mulai membuka HIK dari pukul 17.00 WIB sampai dengan pukul 03.00 WIB dini hari. Bisa terbayangkan bagaimana lelahnya, bahkan ketika diwawancarai Ibu Mulyani sedikit dalam kondisi lelah dan ngantuk terlihat dari kantung mata dan matanya yang begitu merah. Bahkan waktu wawancara, semua pekerja sibuk dengan jobdesknya masing-masing. Ada yang sedang memasak nasi, ada yang sedang membungkus nasi, ada yang sedang menyapu di sekitaran gerobak dikarenakan 
air genangan yang mengganggu konsumen dan ada yang melayani para pembeli. Dengan pembagian kerja yang pasti dan aturan yang diterpakan pada pegawainya angringan dapat mampu mempertahankan usahanya.

Jaringan. Pada dasarnya makananmakanan yang dijual di angkringan, jika kita lihat sebenarnya bukanlah makanan yang elit. Semua makanan yang tersedia di atas gerobak angkringan adalah makanan yang benar sederhana, seperti nasi kucing, tempe, tahu, sate telur puyuh, sate keong, sate kikil, sate kulit ayam, sate usus, baceman serta cemilan lain- lain. Untuk minuman sendiri, biasanya adalah teh panas, jeruk panas, kopi, susu jahe, dan munuman lainnya. Harga yang dijual juga beragam misalnya untuk gorengan berkisar Rp 500 sampai dengan 1500 dan makanan sundukan berkisar antara Rp 1500 sampai dengan Rp 2.500 .

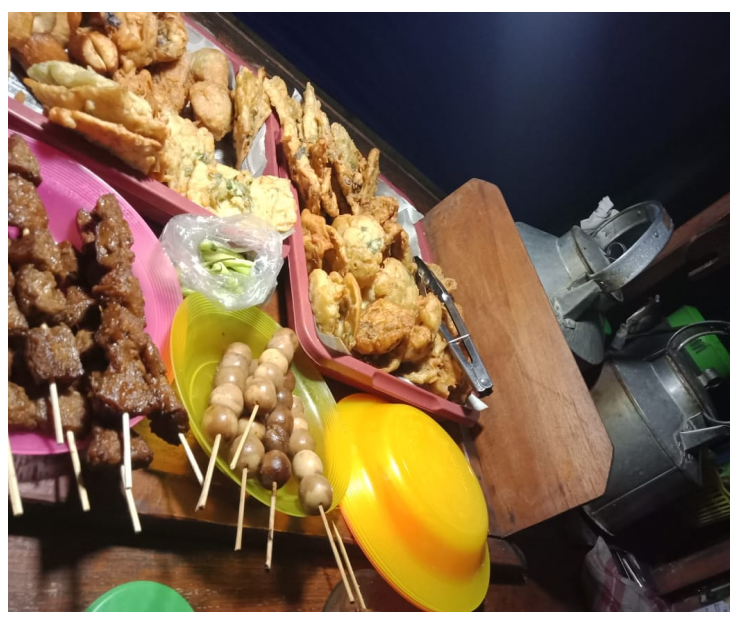

Gambar2. Makanan yang dijual di angkringan (sumber: dokumen pribadi)
Sebagaian besar makanan yang dihidangakan diatas gerobak kayu tersebut ialah makanan titipan. Jadi pemilik angkringan tidak memasak sendiri kemudian dijualnya, namun akan ada beberapa orang yang menitipkan makanannya untuk dijual. Kemudian untuk keuntungan yang didapat dengan cara bagi hasil atau pemilik angkringan menaikkan harga asli makanan. Dengan begitu pemilik angkringan tidak cemas apabila makanan yang dijual tersisa, karena penjual akan tetap mendapatkan keuntungan tanpa merugi atau tanpa mengeluarkan modal. Biasanya sesuatu yang dijual asli dari pemilik angkringan ialah yang berkaitan dengan minuman (wedangan). Bagi pemilik angkringan, wedanganlah yang menyumbang keuntungan paling besar. Pasalnya, hanya dengan bermodalkan air, teh, jeruk dan minuman sachet mampu mendapatkan keuntungan yang besar.

Selain menjaga jaringan dengan supplier makanan, para pedangan angkringan di era disrupsi juga berjejaring dengan para ojek online. Para pedagang angkringan di wilayah Jalan Ki Hadjar Dewantara beberpa sudah terdaftar dalam aplikasi go food dan grabfood. Dengan terdaftarnya pada aplikasi jasa antar tersebut para pedagang juga berjejaring dengan pengemudi ojek online. 


\section{Kesimpulan}

Angkringan adalah salah satu usaha kuliner yang sudah berlangsung berpuluh-puluh tahun. Kota Surakarta memiliki cerita tersendiri mengenai sejarah angkringan. Pada saat ini sudah menjamur usaha informal dengan konsep angkringan baik yang tradisional maupun yang modern. Baik yang tradisional maupun modern berusaha bertahan di era disrupsi. Untuk mempertahankan usaha angkringannya para pedangan melakukan berbagai macam strategi, salah satunya dengan modal social. Ada tiga komponen modal social Putnam (Usman; 2018) yang dilakukan oleh pedagang angkringan, yaitu: Pertama, membangun trust (kepercayaan) pelanggan dengan memberikan pelayanan maksimal, menjaga cita rasa makanan, dan memberikan tempat yang nyaman untu ngobrol. Kedua, memeperketat aturan atau norma pada para pegawainya dengan jobdesk yang sudah ada. Ketiga, membangun jaringan dengan supplier makanan dan membangun jaringan baru dengan para pengemudi ojek online.

\section{Daftar Pustaka}

Marfai, Aris. (2005). ”Angkringan, Sebuah Simbol Perlawanan”, dalam: http://www.penulislepas. com, 13 Agustus 2005.

NN.(2002). “Ting-ting Hik”, Majalah Basis, No. 09-10, Tahun ke-51, September-Oktober 2002.

Noviana Lely Setyowati. (2005). Eksistensi Pengusaha Hik Dan Kepuasan Pelanggan (Studi Diskriptif Kualitatif Tentang Eksistensi Pengusaha Hik Dan Kepuasan Pelanggan Di Sekitar Kampus Universitas Sebelas Maret Surakarta. Skripsi. FISIP. UNS.

Priyatmoko, Heri.(2013). "Melongok Sejarah HIK di Solo". Dalam Joglosemar Edisi Selasa 03 Desember 2013. Surakarta

Priyatmoko, Heri. (2018).Kearifan Angkringan. https://news.detik.com/kolom/d3969893/kearifan-angkringan, (diakses pada tanggal 3 Mei 2019).

Priyatmoko, Heri. (2018).Geger Taman Sriwedari Solo. https://tirto.id/geger-taman-sriwedarisolo-cFtC (diakses pada 2 Maret 2019)

Santoso, Slamet (2007). Peran Modal Sosial terhadap Perkembangan Pedagang Kaki Lima di Ponorogo. ASPIRASI JURNAL ILMU SOSIAL DAN POLITIK 17 (1), 96-107

Tonkiss, F. (2000). Trust Social Capital and Economy. Dalam F. Tonkiss and Pasey (ed). Trust and Civil Society. New York: St.Martin's

Usman, Sunyoto. (2018).Modal Sosial. Yogyakarta: Pustaka Pelajar

Qomaria, Issrotul. (2015). Strategi Survival Pedagang Angkringan (Studi Tentang Modal Sosial Angkringan Dalam Menghadapi Persaingan Antar Usaha Warung Makan di Kota Yogyakarta dan Sekitarnya). Skripsi. Universitas Gadjah Mada, 2015. Diunduh dari http://etd.repository.ugm.ac.id/

Yudhistira, Bara; Haryani, Tiyas Nur, dan Hadi Nurcahyono, Okta. (2018).Angkringan Development as a Traditional Culinary Identity. International Conference on Small and Medium Enterprise Empowerment, ICSMEE 2018, Surakarta: 10 Oktober 2018. Hal. 38-43. 
Habitus: Jurnal Pendidikan Sosiologi dan Antropologi Vol. 3 No. 1 Tahun 2019 hal. 41-50

ISSN: 2597-9264 